\title{
Effects of Chronic Sucralose Sweetener on the Labeling of Blood Constituents with Technetium-99m, Morphology of Red Blood Cells and the Biodistribution of Sodium Pertechnetate in Rats
}

\author{
Gabrielle de Souza Rocha ${ }^{1,2}$, Marcia de Oliveira Pereira ${ }^{1,2}$, Mônica de Oliveira Benarroz ${ }^{2}$, \\ Jacques Natan Grinapel Frydman ${ }^{1,2}$, Angélica Beatriz Garcia-Pinto ${ }^{2}$, Mário José Pereira ${ }^{3}$, \\ Adenilson de Souza da Fonseca ${ }^{2,4, *}$ and Mario Bernardo-Filho ${ }^{2,5}$ \\ ${ }^{I}$ Centro de Ciências da Saúde; Universidade Federal do Rio Grande do Norte; Av. General Gustavo Cordeiro de \\ Farias, s/n; 59010180; Natal - RN - Brasil. ${ }^{2}$ Departamento de Biofísica e Biometria; Instituto de Biologia Roberto \\ Alcantara Gomes; Universidade do Estado do Rio de Janeiro; Rio de Janeiro - RJ - Brasil. ${ }^{3}$ Departamento de \\ Fisiologia; Av. 28 de Setembro, 87; Vila Isabel; 20551030; Rio de Janeiro - RJ - Brasil. ${ }^{4}$ Centro de Ciências da \\ Saúde; Centro Universitário Serra dos Órgãos; Av. Alberto Torres, 111; 25964004; adenilso@uerj.br; Teresópolis \\ - RJ - Brasil. Instituto Nacional do Câncer; Praça Cruz Vermelha, 23; 20230130; Rio de Janeiro - RJ - Brasil
}

\begin{abstract}
This work evaluates effects of the sweetener with sucralose on the labeling of blood constituents with technetium$99 m\left({ }^{99 m} T c\right)$, on the morphology of red blood cells $(R B C)$ and on the biodistribution of sodium pertechnetate in Wistar rats. Animals were treated with sweetener for 8 days. Blood samples were withdrawn and the assay of labeling of blood constituents with ${ }^{99 m}$ Tc was performed. Blood cells $(B C)$ and plasma $(P)$ were isolated. Aliquots of $B C$ and $P$ were also precipitated, soluble and insoluble fractions separated. The radioactivity in each fraction was counted and percentage of incorporated radioactivity (\%ATI) determined. Blood smears were prepared, fixed, stained and the qualitative and quantitative morphology of the RBC was evaluated under optical microscopy. In biodistribution experiments, sodium pertechnetate was administrated, organs and tissues isolated, radioactivity was counted and percentage of incorporated radioactivity per gram (\%ATI/g) determined. The data showed no significant alterations in \%ATI, morphology of RBC and in \%ATI/g in the studied organs.
\end{abstract}

Keywords: biodistribution, blood, morphology, sweetener, technetium-99m

\section{INTRODUCTION}

Sucralose is a non-caloric and non-nutritive sweetener derived from sucrose, has high water solubility and excellent physico-chemical stability (Mann et al., 2000). This sweetener is used in foods and beverages, as well as in baking, without loss of sweetness during processing and storage presenting safety for human consumption (Grice and Goldsmith, 2000).

Other studies in animals and humans have shown that sucralose is not hydrolysed in the intestinal

\footnotetext{
* Author for correspondence
} 
lumen, to exhibit limited absorption, rapid urinary excretion and faecal excretion in an unchanged form (John et al., 2000). Plasma peak concentration is about 2 hours (1.0 a 3 hours) after the oral dose (Baird et al., 2000; Roberts et al., 2000).

At higher doses, sucralose decreases diet palatability, food consumption, food conversion efficiency as well as body and organ weight gain (Goldsmith, 2000).

Red blood cells (RBC) labeled with technetium$99 \mathrm{~m}\left({ }^{99 \mathrm{~m}} \mathrm{Tc}\right)$ is used as radiopharmaceutical in nuclear medicine (Olds et al., 2005). Labeling of blood constituents with ${ }^{99 \mathrm{~m}} \mathrm{Tc}$ has been successfully used as assay to evaluate the interference of in vitro or in vivo treatment with synthetic or natural products with radiopharmaceuticals (Fonseca et al., 2007; Benarroz et al., 2008). Moreover, the analysis of the morphology of the RBC has been used a method to evaluate the effects of drugs on shape of these cells (Frydman et al., 2008).

The radiopharmaceutical sodium pertechnetate is uptaken by stomach, intestinal tract, thyroid and salivary glands (Saha, 2004). However, factors as synthetic or natural drugs, dietary conditions could affect the biodistribution of radiopharmaceuticals (Bernardo-Filho et al., 2005).

Although widely consumed by diabetics and by subjects for weight control, no data about diary consumption of sucralose sweetener and the biodistribution of radiopharmaceuticals or effects upon the shape of RBC have been described. Thus, the aim of this work was to evaluate the in vivo effects of chronic treatment with sucralose sweetener on the labeling of blood constituents with ${ }^{99 \mathrm{~m}} \mathrm{Tc}$, on the morphology of the RBC, and on the biodistribution of sodium pertechnetate.

\section{MATERIAL AND METHODS}

\section{Animals}

Wistar rats (3-4 months, 250-350g) were housed in an environmentally-controlled room $\left(25 \pm 2{ }^{\circ} \mathrm{C}\right)$, with free access to water and food. Experimental procedures were conducted in accordance with the Department Committee of Animal Care of the Instituto de Biologia Roberto Alcantara Gomes, Universidade do Estado do Rio de Janeiro (protocol number CEA/134/2006).

\section{Sweetener}

The commercial sweetener with sucralose (Linea $\AA$, lot 060908 , expiration date, September 2008) used in this study was purchased from Linea Nutrição e Ciência (Brazil).

\section{Chronic sweetener treatment}

For radiolabeling and morphological evaluation of $\mathrm{RBC}$, the animals ( $\mathrm{n}=10$, for each dose) were treated with sweetener at different doses $(0.5,5$ and $50 \mathrm{mg} / \mathrm{kg}$ ) for 8 days. For biodistribution procedure, the animals $(\mathrm{n}=12$, for each dose) were treated with sweetener $(0.5$ and $50 \mathrm{mg} / \mathrm{kg})$ for 8 days. As control groups, animals $(n=10)$ were treated with saline solution $(0.9 \% \mathrm{NaCl})$. The sweetener solutions were prepared immediately before the experimental procedures.

\section{Labeling of blood constituents with ${ }^{99 \mathrm{~m}} \mathrm{Tc}$}

Samples of heparinized blood were withdrawn from animals 24 hours after sweetener treatment. This labeling assay was described elsewhere (Bernardo-Filho et al., 1983). Briefly, stannous chloride solution $(1.20 \mu \mathrm{g} / \mathrm{ml}$ ) (Sigma Chemical Co., St Louis, USA) was added and incubation continued for 60 minutes at room temperature. After this period of time, ${ }^{99 \mathrm{~m}} \mathrm{Tc}(3.7 \mathrm{MBq})$, as sodium pertechnetate $\left(\mathrm{Na}^{99 \mathrm{~m}} \mathrm{TcO}_{4}\right)$, recently milked from a ${ }^{99} \mathrm{Mo} /{ }^{99 \mathrm{~m}} \mathrm{Tc}$ generator (Instituto de Pesquisas Energéticas e Nucleares, Comissão Nacional de Energia Nuclear, Brazil) were added and incubation was continued for 10 minutes. These samples were centrifuged (1500 rpm, $5 \mathrm{~min}$ ) to separate plasma (P) and blood cells (BC). Aliquots of $\mathrm{P}$ and $\mathrm{BC}$ were also precipitated in trichloroacetic acid (5\%) solution and centrifuged (1500 rpm, $5 \mathrm{~min}$ ) to isolate soluble (SF) and the insoluble fractions (IF). The radioactivity in each aliquot of P, BC, SF-P, IF-P, SF-BC and IF-BC were determined in a well gamma-counter (Automatic Gamma Counter, Packard Instrument Co, Illinois, USA) and the percentage of incorporated radioactivity (\%ATI) was calculated as described elsewhere (Bernardo-Filho et al., 1983).

\section{Morphological evaluation of red blood cells}

Smears were prepared with blood samples from animals in vivo treated with sweetener or with saline solution as control group, dried, fixed and stained by May-Grünwald-Giensa method 
(Junqueira and Carneiro, 2004). Five slides per blood sample were analyzed and five fields were evaluated per slide. After that, images of the RBC were acquired (Optronics, USA) from slides for qualitative morphology analysis under optical microscopy (x1000, Olympus, BX model, Japan). For morphometric analysis of RBC, the perimeter/area ratio was obtained from images by specific program (Image ProPlus Software, USA).

\section{Biodistribution of sodium pertechnetate}

After the in vivo treatment with sweetener or saline, $\mathrm{Na}^{99 \mathrm{~m}} \mathrm{TcO}_{4}(3.7 \mathrm{MBq})$ were injected by ocular plexus and the animals were sacrificed 10 minutes later. Organs were isolated and weighed (pancreas, testis, stomach, kidney, spleen, intestine, heart, lung, liver, thyroid, bone, muscle, brain and blood), and radioactivity was counted in a well counter (Automatic Gamma Counter, Packard Instrument Co, Illinois, USA). The percentage radioactivity per gram of each tissue or organ $(\% \mathrm{ATI} / \mathrm{g})$ was calculated as described elsewhere (Moreno et al., 2007).

\section{Statistical analysis}

Data is reported as (means $\pm \mathrm{SD}$ ) from radiolabeling assay (\%ATI), perimeter/area ratio and $\% \mathrm{ATI} / \mathrm{g}$. Each treated group was compared with control group by One way analysis of variance-ANOVA with a $p<0.05$. InStat Graphpad software was used to perform statistical analysis (GraphPad InStat version 3.00 for Windows 95, GraphPad Software, San Diego California, USA).

\section{RESULTS}

Figure 1 shows the effect of chronic in vivo treatment with sweetener at different doses for 8 days on the labeling of blood cells (BC), insoluble fraction of plasma (IF-P) and insoluble fraction of blood cells (IF-BC) with ${ }^{99 m}$ Tc. The results indicate that the sweetener was not capable of significantly altering $(p>0.05)$ the radiolabeling of blood constituents.

Figures 2 and 3 represent photomicrographs of the blood smears from animals treated with saline solution (control) and with an aqueous sweetener solution at the highest dose used $(50 \mathrm{mg} / \mathrm{kg}$ ) for 8 days. Qualitative morphological analysis by the comparison between these figures suggests that the sweetener solution used did not induce important changes on shape of RBC when observed under optical microscopy.

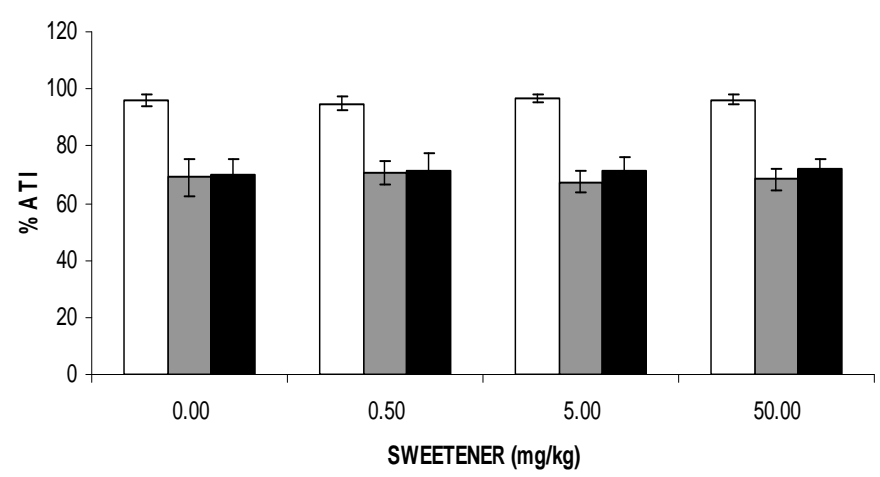

Figure 1 - Effect of chronic in vivo treatment with sweetener on the labeling of blood constituents with ${ }^{99 \mathrm{~m}} \mathrm{Tc}$. Wistar rats were treated with sweetener for 8 days. ( $\square$ ) Blood cells, ( $\square$ ) insoluble fraction of plasma, ( $\mathbf{\square})$ insoluble fraction of blood cells. 


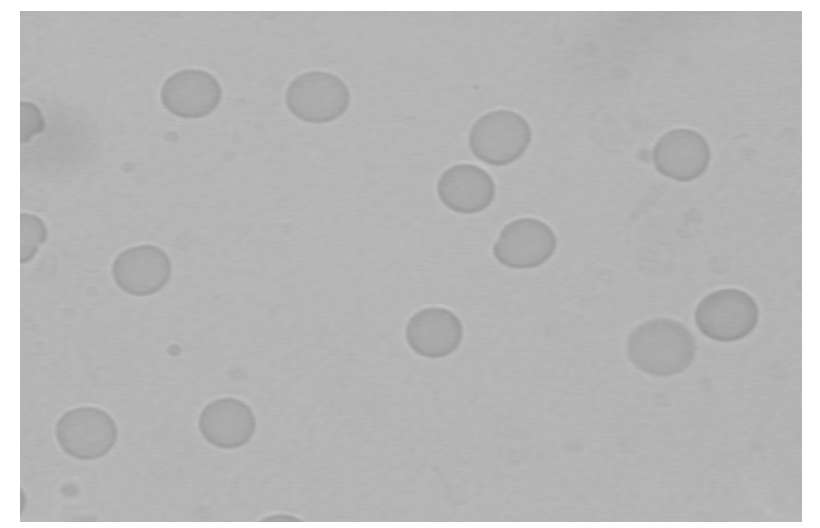

Figure 2 - Photomicrography of blood smears from animals treated with saline (control group). Blood smears were prepared, dried, fixed and staining by May-Grünwald-Giensa method. The morphology of red blood cells was evaluated under optical microscopy (x1000) after image capture.

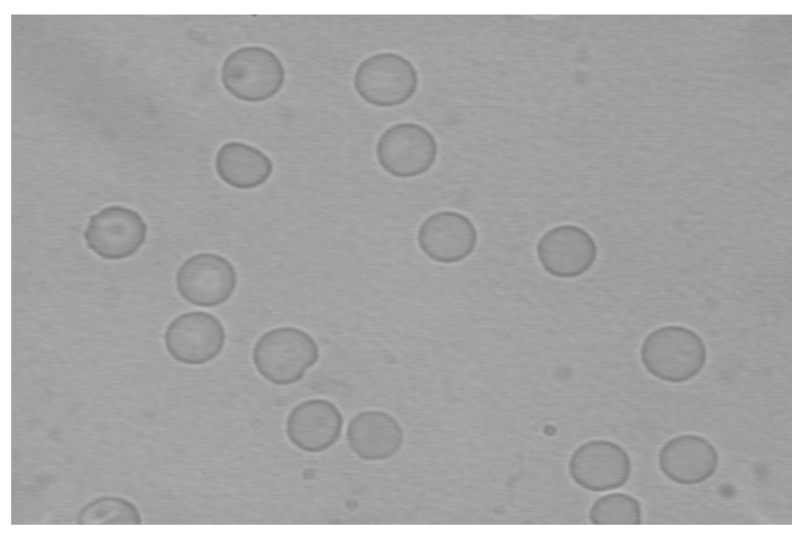

Figure 3 - Photomicrography of blood smears from animals was treated with sweetener $(50 \mathrm{mg} / \mathrm{kg})$ for 8 days. Blood smears were prepared, dried, fixed and staining by May-GrünwaldGiensa method. The morphology of red blood cells was evaluated under optical microscopy (x1000) after image capture.

The perimeter/area ratio of $\mathrm{RBC}$ from animals treated with an aqueous sweetener solution at different doses for 8 days is shown in Figure 4. This data suggests that no modification on perimeter/area ratio of the $\mathrm{RBC}$ is induced by chronic in vivo sweetener treatment.
The effect of sweetener treatment on the biodistribution of radiopharmaceutical sodium pertecnetate is shown in Table 1. Data in this table indicate that treatment with sweetener did not alter significantly $(p>0.05)$ the biodistribution of sodium pertechnetate on organs and tissues evaluated. 


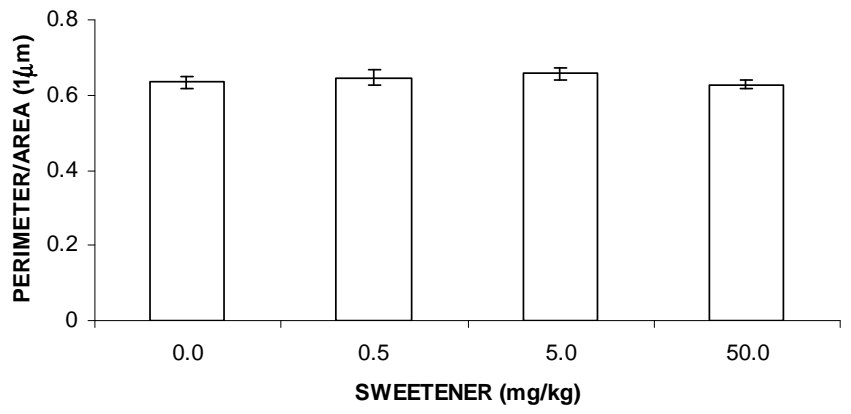

Figure 4 - Effect of chronic in vivo treatment with sweetener on the perimeter/area ratio of RBC from animals treated with sweetener for 8 days. Morphology of RBC was evaluated under optical microscopy (x1000) after image captures, morphometric measurements (perimeter and area) were carried out and perimeter/area calculated.

Table 1 - Effects of the sweetener on the biodistribution of sodium pertechnetate in Wistar rats.

\begin{tabular}{cccc}
\hline Organs & & \%ATI/g & \\
\cline { 2 - 4 } and & & Sweetener $(\mathbf{m g} / \mathbf{k g})$ & $\mathbf{5 0 . 0 0}$ \\
\cline { 2 - 4 } tissues & $\mathbf{0 . 0 0}$ & $\mathbf{0 . 5 0}$ & $0.38 \pm 0.05$ \\
Pancreas & $0.20 \pm 0.04$ & $0.37 \pm 0.07$ & $0.13 \pm 0.01$ \\
Testycle & $0.14 \pm 0.01$ & $1.12 \pm 0.01$ & $1.44 \pm 0.09$ \\
Stomach & $2.02 \pm 0.38$ & $0.57 \pm 0.05$ & $0.56 \pm 0.05$ \\
Kidney & $0.58 \pm 0.04$ & $0.30 \pm 0.03$ & $0.34 \pm 0.03$ \\
Spleen & $0.29 \pm 0.03$ & $0.49 \pm 0.07$ & $0.52 \pm 0.04$ \\
Intestine & $0.36 \pm 0.05$ & $0.24 \pm 0.03$ & $0.34 \pm 0.03$ \\
Heart & $0.33 \pm 0.03$ & $0.84 \pm 0.08$ & $0.89 \pm 0.06$ \\
Lung & $0.68 \pm 0.03$ & $0.60 \pm 0.06$ & $0.58 \pm 0.04$ \\
Liver & $0.50 \pm 0.04$ & $3.25 \pm 0.68$ & $3.57 \pm 0.34$ \\
Tyroid & $4.53 \pm 0.69$ & $0.21 \pm 0.02$ & $0.19 \pm 0.01$ \\
Bone & $0.15 \pm 0.01$ & $0.10 \pm 0.01$ & $0.11 \pm 0.01$ \\
Muscle & $0.11 \pm 0.01$ & $0.04 \pm 0.01$ & $0.04 \pm 0.01$ \\
Brain & $0.04 \pm 0.01$ & $1.10 \pm 0.11$ & $1.33 \pm 0.10$ \\
Blood & $1.05 \pm 0.07$ &
\end{tabular}

Effects of the sweetener on the biodistribution of $\mathrm{Na}^{99 \mathrm{~m}} \mathrm{TcO}_{4}$ in Wistar rats. Animals were treated with sweetener for 8 days or with saline solution as control group, $\mathrm{Na}^{99 \mathrm{~m}} \mathrm{TcO}_{4}$ was administered, organs and tissues were isolated and weighed. Radioactivity was counted and the percentages of radioactivity per gram of each organ $(\% \mathrm{ATI} / \mathrm{g})$ were calculated.

\section{DISCUSSION}

In this study the effects of a chronic in vivo treatment with sweetener on the radiolabeling of blood constituents, on the qualitative and quantitative morphology of the RBC and on the biodistribution of $\mathrm{Na}^{99 \mathrm{~m}} \mathrm{TcO}_{4}$ were evaluated. The concentrations and treatment time with sweetener used were similar to plasma peak concentration (ranging 141 to $455 \mathrm{ng} / \mathrm{ml}$ ) and the time to peak blood levels (1.0 to $3 \mathrm{~h}$ ) in human beings reported by Roberts et al. (2000) and Baird et al. (2000).

The results obtained in this study by radiolabeling assay indicate that the sweetener solutions have not affected the labeling of blood constituents (Figure 1). In the assay of labeling of blood constituents with ${ }^{99 \mathrm{~m}} \mathrm{Tc}$, cellular (hemoglobin) and plasma proteins are labeled and a reducing agent is 
necessary (Early and Soddee, 1995; Owunwanne et al., 1995). Some authors have suggested that sucralose treatment does not alter the glycated hemoglobin (Grotz et al., 2003; Reyna et al., 2003) and C-peptide levels (Mezitis et al., 1996) as well as serum biochemistry (Baird et al., 2000). Thus, the compounds present in sweetener used would not present redox action or interact with sites on plasma or cellular proteins related with the ${ }^{99 \mathrm{~m}} \mathrm{Tc}$. No qualitative alteration on the shape of the RBC from Wistar rats treated with sweetener was observed (Figures 2 and 3). This result was confirmed by the quantitative morphological analysis (perimeter/area ratio) of these cells (Figure 4). Studies have demonstrated that sucralose has not induced morphological modifications on cells of central nervous system (Grice and Goldsmith, 2000). In addition, other data have suggested no alteration on haematologic profile after treatment with this sweetener. However, in these studies were not investigated the effects of sucralose on RBC (Baird et al., 2000).

Taken together, the data obtained with assay of radiolabeling of blood constituents and morphological analysis suggest that the chronic in vivo treatment with sweetener used did not present important effects on the membrane of $\mathrm{RBC}$ and could not influence the ion membrane transport systems.

Data obtained in the biodistribution assay indicates that chronic in vivo treatment with sweetener could not also alter the uptake of $\mathrm{Na}^{99 \mathrm{~m}} \mathrm{TcO}_{4}$ in specific organs and tissues (Table 1). The development of models to study the normal biodistribution and elimination pattern of sucralose may help to understand the sweetener interaction with radiopharmaceuticals and to observe of the possible change. Moreover, these findings are relevant to justify the use of the sucralose by the human beings.

In conclusion, the results presented in this study have important interest to a better understanding of the actions of the sucralose sweetener on blood constituents and on the interactions with radiopharmaceuticals. Moreover, the experimental models used could be worthwhile so as to verify some properties related with chemical compounds that the human beings could be using daily.

\section{ACKNOWLEDGEMENTS}

This study was supported by grants and financial aid from CAPES, CNPq and FAPERJ.

\section{RESUMO}

Neste estudo foram avaliados efeitos do adoçante com sucralose na marcação de constituintes sangüíneos com ${ }^{99 \mathrm{~m}} \mathrm{Tc}$, na morfologia de hemácias e na biodistribuição do pertecnetato de sódio em ratos Wistar. Animais foram tratados com adoçante durante 8 dias. Amostras de sangue foram retiradas e a marcação de constituintes sanguiíneos com ${ }^{99 \mathrm{~m}} \mathrm{Tc}$ foi realizada. Células sangüíneas (CS) e plasma (P) foram isolados. Alíquotas de CS e P foram precipitadas, frações insolúvel e solúvel foram separadas. A radioatividade em cada fração foi contada e o percentual de radioatividade incorporada (\%ATI), determinado. Distensões sangüíneas foram preparadas, fixadas, coradas e análise morfológica, qualitativa e quantitativa, de hemácias foi avaliada sob microscopia óptica. Nos experimentos de biodistribuição, pertecnetato de sódio foi administrado, órgãos e tecidos isolados, a radioatividade contada e o percentual de radioatividade incorporada por grama $(\% \mathrm{ATI} / \mathrm{g})$, determinada. Os dados sugerem que não houve alterações significativas no \%ATI, morfologia de hemácias e no \%ATI/g.

\section{REFERENCES}

Baird, I. M.; Shephard, N. W.; Merritt, R. J.; HildickSmith, G. (2000), Repeated dose study of sucralose tolerance in human subjects. Food Chem Toxicol., 38 (Suppl. 2), 123-129.

Benarroz, M. O.; Fonseca, A. S.; Rocha, G. S.; Frydman, J. N.; Rocha, V. C.; Pereira, M. O.; Bernardo-Filho, M. (2008), Cinnamomum zeylanicum extract on the radiolabelling of blood constituents and the morphometry of red blood cells: In vitro assay. Appl Radiat Isot., 66, 139-146.

Bernardo-Filho, M.; Moura, I. N. S.; Boasquevisque, E. M. (1983), ${ }^{99 \mathrm{~m}}$ Technetium-labeled red blood cells "in vitro”. Arq Bras Biol Tecnol., 26, 455-461. 
Bernardo-Filho, M.; Santos-Filho, S. D.; Moura, E. G.; Maiworn, A. I.; Orlando, M. M. C.; Penas, M. E.; Cardoso, V. N.; Bernardo, L. C.; Brito, L. C. (2005), Drug interaction with radiopharmaceuticlas: a review. Braz Arch Biol Technol., 48, 13-27.

Early, P. J.; Soddee, D. B. (1995), Principles and Practice of Nuclear Medicine. Mosby, London.

Fonseca, A. S.; Frydman, J. N. G.; Rocha, V. C.; Bernardo-Filho, M. (2007), Acetylsalicylic acid decreases the labeling of blood constituents with technetium-99m. Acta Biol Hung., 58, 187-98.

Frydman, J. N. G.; Rocha, V. C.; Benarroz, M. O.; Rocha, G. S.; Pereira, M. O.; Fonseca, A. S.; Bernardo-Filho, M. (2008), Assessment of effects of a Cordia salicifolia extract on the radiolabeling of blood constituents and on the morphology of red blood cells. J Med Food, in press.

Goldsmith, L. A. (2000), Acute and Subchronic Toxicity of Sucralose. Food Chem Toxicol., 38 (Suppl. 2), 53-69.

Grice, H. C.; Goldsmith, L. A. (2000), Sucralose: an overview of the toxicity data. Food Chem Toxicol., 38 (Suppl. 2), 1-6.

Grotz, V. L.; Henry, R. R.; McGill, J. B.; Prince, M. J.; Shamoon, H.; Trout, J. R.; Pi-Sunyer, F. X. (2003), Lack of effect of sucralose on glucose homeostasis in subjects with type 2 diabetes. J Am Dietetics Ass., 103, 1607-1612.

John, B. A.; Wood, S. G.; Hawkins, D. R. (2000), The pharmacokinetics and metabolism of sucralose in the rabbit. Food Chem Toxicol., 38 (Suppl. 2), 111-113.

Junqueira, L. C.; Carneiro, J. (2004), Histologia Básica. Guanabara Koogan, Rio de Janeiro.

Mann, S. W.; Yuschak, M. M.; Amyes, S. J. G.; Aughton, P.; Finn, J. P. (2000), A combined chronic toxicity/carcinogenicity study of sucralose in
Sprague-Dawley rats. Food Chem Toxicol., 38 (Suppl. 2), 71-89.

Mezitis, N. H.; Maggio, C. A.; Koch, P.; Quddoos, A.; Allison, D. B.; Pi-Sunyer, F. X. (1996), Glycemic effect of a single high oral dose of the novel sweetener sucralose in patients with diabetes. Diabetes Care, 19, 1004-1005.

Moreno, S. R. F.; Silva, A. L. C.; Diré, G.; Honeycut, H.; Carvalho, J. J.; Nascimento, A. L.; Pereira, M.; Rocha, E. K.; Oliveira-Timóteo, M.; Arnobio, A.; Olej, B.; Bernardo-Filho, M.; Caldas, L. Q. A. (2007), Effect of oral ingestion of an extract of the herb Uncaria tomentosa on the biodistribution of sodium pertechnetate in rats; Braz J Med Biol Res, 40, 77-80.

Olds, G. D.; Cooper, G. S.; Chak, A.; Sivak, M. V. Jr.; Chitale, A. A.; Wong, R. C. (2005), The yield of bleeding scans in acute lower gastrointestinal hemorrhage. J Clin Gastroenterol., 39, 273-277.

Owunwanne, A.; Patel, M.; Sadek, S. (1995), The Handbook of Radiopharmaceuticals, Chapman and Hall, London.

Reyna, N. Y.; Cano, C.; Bermudez, V. J.; Medina, M. T.; Souki, A. J.; Ambard, M.; Nunez, M.; Ferrer, M. A.; Inglett, G. E. (2003), Sweeteners and beta-glucans improve metabolic and anthropometrics variables in well controlled type 2 diabetic patients; Am J Therapeutics, 10, 438-443.

Roberts, A.; Renwick, A. G.; Sims, J.; Snodin, D. J. (2000), Sucralose Metabolism and Pharmacokinetics in Man. Food Chem Toxicol., 38 (Suppl. 2), 31-41.

Saha, G. B. (2004), Fundamentals of Nuclear Pharmacy, Springer-Verlag, New York.

Received: August 20, 2008; Revised: September 10, 2008; Accepted: September 12, 2008. 